\section{Improving Productivity of Open-pollinated Processing Tomato Cultivars}

\author{
Ibrahim Duman, Eftal Düzyaman, Dursun Esiyok, and Hüseyin Vural \\ Ege University, Faculty of Agriculture, Department of Horticulture, 35100 \\ Bornova, Izmir, Turkey
}

\section{Semih Erkan \\ Ege University, Faculty of Agriculture, Department of Plant Protection, 35100 Bornova, Izmir, Turkey}

Additional index words. mass selection, yield, low input agriculture, genetic drift

\begin{abstract}
In contrast to developed countries open-pollinated (OP) processing tomato cultivars still have a certain market value in Turkey. A total of 26 subpopulations of 6 different OP cultivars (9 of Rio Grande, 5 of Rio Fuego, and 3 of each of C-37, Interpeel, T2 Improved, and VF 6203) were evaluated in two experimental sites in Marmara Region and Aegean Region. A high degree of phenotypic variance for yield (kg/plant) was found for most subpopulations which revealed the variation for yield amongst individuals, and hence the possibility to select for superior plants. Eighteen populations were developed by two cycles of mass selection conducted within the initial populations in both regions. Most progeny populations significantly exceeded their source cultivars in yield. Heritability estimates occurred generally parallel to that of yield increases of the progenies, which were slightly higher in the Karacabey trial (Marmara Region) as compared to the Muradiye trial (Aegean Region). Results were discussed from the point of view of the resource-poor farmers conducting low-input agriculture.
\end{abstract}

The establishment of processing tomato (Lycopersicon esculentum Mill.) companies in Turkey dates back to 1960 s, which today, after half a century, produce 250,000 to $300,000 \mathrm{t}$ of tomato paste each year (Blake et al., 2003). At the beginning, the production was essentially based on open-pollinated (OP) tomato cultivars with little improved traits for technological processing (Vural et al., 2000). This has changed in 1970'ties with the introduction of the OP cultivar Rio Grande, which covered a great proportion of the growing areas for many years (Vural et al., 2000). The loosening of restrictions in seed import in Turkey between 1983 and 1984 resulted in an explosion in the importation of varietal seeds, especially in that of the hybrids, which elevated the level of hybrid use in processing tomato production in Turkey to a similar level as it was in California (Grandillo et al., 1999; Turkish Republic Ministry of Agricultural and Rural Affairs, 2002). It is documented that the ratio of OPs vs. hybrids decreased drastically in processing tomato fields in the last 40 years

Received for publication 2 Mar. 2005. Accepted for publication 4 June 2005. The researchers are grateful to the Scientific and Technical Research Council of Turkey (TUBITAK), which has financially supported this work. We would also express our thanks to the seed companies Agromar Tarım Ürünleri San. Tic. A.S., Beta Ziraat Ticaret A.S., MAY Tohum Grubu, and TAT Tohumculuk A.S.; and to the paste companies Demko Demirci Konservecilik A.S., Öztusan Salça Konserve A.S., and Tukas Gıda Sanayi Ticaret for supplying the seed material and collaborating in the field experiments. We are also very grateful to Metin Birkan Yıldırım and the anonymous reviewers for their thoughtful review of the manuscript. in Turkey (Erkan et al., 1996; Vural, 1966). For instance, while $60 \%$ of the processing tomato fields were OPs in 1991, only $20 \%$ remained in 1996, which is being estimated to be even lower today (Blake et al., 2003; Erkan et al., 1996). Parallel to these developments, fresh yield was considerably improved from about 1966; Vural et al., 2000), a performance that is higher than China (23.9 th ha ${ }^{-1}$ ) or India (14.3 $\left.\mathrm{t} \cdot \mathrm{ha}^{-1}\right)$, however still lower than European countries (44.7 to $59.7 \mathrm{t} \cdot \mathrm{ha}^{-1}$ ) and the U.S. (62.5 tha $\mathrm{ha}^{-1}$ ) (FAOSTAT, 2004).

The use of hybrids vs. OPs in the domestic production is a critical discussion point, which should take the socioeconomic status of the rural areas into consideration (Vural et al., 2000). In contrast to the OP cultivars which are mostly reproduced in Turkey, hybrid seeds are costly and are almost always imported (Turkish Republic Ministry of Agricultural and Rural Affairs, 2002). Their high prices do not fit to the agricultural production system of Turkey, which is still largely based on smallscale farmers with limited resources (Blake et al., 2003; Erkan et al., 1996). Hence, the impact of industrialization in the food sector and increasing amounts of export has affected the socioeconomic status of the farmer only to a limited extent, since most of the profits are given to mediators and marketing experts, especially when there is no contract agreement between the farmers and the food companies. On the other hand, OP cultivars do not meet the current requirements of the Turkish processing tomato production due to several global reasons among which low or unstable yield and lack of resistance to pests and diseases are the $20 \mathrm{t} \cdot \mathrm{ha}^{-1}$ in $1960 \mathrm{~s}$ to $42.4 \mathrm{t} \cdot \mathrm{ha}^{-1}$ in 2000 (Vural, most pronounced (Gallardo and Calvar, 1992; Grandillo et al., 1999).

It is a common phenomenon that even after a few generation cycles OP cultivars run out by loosing their characteristics. This study was conducted to examine current OP processing tomato cultivars for the possibility of improving their productivity by applying simple selection procedures. An increase in fruit yield of current OP cultivars would facilitate increases in the growing rate of OPs vs. hybrids, which in turn, will serve small-scale farmers conducting low-input agriculture.

\section{Materials and Methods}

Twenty six subpopulations from six cultivars were used for this study. Cultivars were derived from seven companies involved in the production and marketing of OP cultivars in Turkey, which are designated as random sources from 1 to 7 throughout text. 'C-37', 'Rio Fuego', 'Rio Grande', and 'T2 Improved' are late cultivars, while 'Interpeel' and 'VF 6203' are early cultivars. 'Rio Grande' (Yalova) was developed by the Atatürk Central Horticultural Research Institute in Yalova Province (unpublished data). Seed samples were screened for tomato mosaic virus (ToMV) and bacterial cancer (Clavibacter michiganensis subsp. michiganensis $=$ C.m.m.) and only pathogen-free cultivars were considered for the experiment.

The experiment was carried out at two sites simultaneously where the production of processing tomatoes is intensified in Turkey, the Marmara Region, Bursa Province, Karacabey District; and the Aegean Region, Manisa Province, Muradiye District. The Karacabey trials were located about $270 \mathrm{~km}$ northeast; and the Muradiye trials about $50 \mathrm{~km}$ east of the Ege University, Faculty of Agriculture Department of Horticulture in Bornova District, Izmir Province, latitude $38^{\circ} 28^{\prime} \mathrm{N}$, longitude $27^{\circ} 15^{\prime} \mathrm{E}$, altitude $25 \mathrm{~m}$.

A general evaluation combined with a mass selection procedure of well-performing individuals was carried out in the first experimental year conducted in 2001 in both regions (Table 1). The same procedure continued in 2002, which gave together two selection cycles conducted separately in two regions. Three harvests were carried out in each trail which were totaled at the end of the growing season to estimate total yield $\left(\mathrm{t} \cdot \mathrm{ha}^{-1}\right)$. Number of fruit per plant was taken as a simple criterion in deciding on the yield of each individual plant. High yielding individuals at the first harvest were marked and followed through the second and third harvests. Plants with consistently high yields were considered for the selection. Seeds from the selected individuals were only extracted from the first harvest and bulked together at the basis of the subpopulations, while those from different subpopulations of a cultivar were kept separate.

Selected populations were compared against their source cultivars in two replicated field trials conducted at both sites in 2003. A completely randomized block design with three replications was used for this purpose, 
where plots consisted of 2 rows with 25 plants per row. In all trials rows were spaced 1.40 $\mathrm{m}$ apart and plants within rows $0.25 \mathrm{~m}$ apart. All trials were conducted in grower fields controlled by the companies in collaboration. Cultural operations were carried out according local practices.

The fruit juice was extracted from samples taken at the first harvest using a warring blender and filtered. ${ }^{\circ}$ Brix was read on a hand type refractometer. ${ }^{\circ}$ Brix $\times$ yield $\left({ }^{\circ} \mathrm{B} \times \mathrm{Y}\right)$ was determined by multiplying the yield in $\mathrm{kg} /$ plant by the ${ }^{\circ}$ brix value and dividing by 100 as suggested by Eshed et al. (1996).

Analysis of variance was carried out for each cultivar group separately using SPSS version 11.0 to compare progenies with 1 ) their own parental sources and 2) with progenies of the same cultivar but of other parental sources. Yield per plant and the derived parameter ${ }^{\circ} \mathrm{B} \times$ $\mathrm{Y}$ were tested in this analysis assuming progenies and sources as main factors and locations as random variables. Comparisons of cultivar means was made by Duncan's multiple range test at $p=0.05$. Phenotypic variance $\left(\sigma^{2}\right)$, and heritability $\left(h^{2}\right)$ were both based on $\mathrm{kg}$ of fruits per plant. $\sigma_{p}^{2}$, which denotes the phenotypic standard deviation in yield ( $\mathrm{kg} / \mathrm{plant})$ of the respective populations, was estimated in the initial populations by sampling. The realized heritability $h^{2}$ was estimated by the common technique of regression of cumulative response on cumulative selection differential, where the slope of the regression denotes heritability $\left(h^{2}\right.$ =b) (Falconer, 1989).

\section{Results}

A total of 23,264 individual plants were initially evaluated in field trials conducted at both locations (Table 1), where 363 to 545 individuals of each subpopulations was screened for the possibilities of isolating superior individuals. Selection for abundant number of fruits was possible in most cultivars. Attention was given to choose the selected plants 1) from different cultivar groups and 2) within the same cultivar at both locations. A total of 178 plants were selected in Karacabey district, while 191 plants in Muradiye district, which together account for $1.59 \%$ of the total number of plants evaluated. The degree of $\sigma^{2}$ for each cultivar was differing for both regions, being generally higher at the Karacabey trial, than at the Muradiye trial, by reaching a peak of 2.03 in 'VF 6203' from source 5. Selection was not performed in five cultivars at the Karacabey trial and in four cultivars in the Muradiye trial due to low $\sigma^{2}$ values.

Acomparison of yield and ${ }^{\circ} \mathrm{B} \times \mathrm{Y}$ of selected individuals with their source cultivars after two cycles of selection is presented in Table 2. Even though the selection was based on fruit yield only, improvements in ${ }^{\circ} \mathrm{B} \times \mathrm{Y}$ occurred parallel to that in yield. The differences in yield and ${ }^{\circ} \mathrm{B} \times \mathrm{Y}$ was significant at $p<0.01$ or at $p$ $<0.05$ in all cultivars for both regions. Since changes in ${ }^{\circ}$ brix values between sources and their progenies were not significant (data not presented), increases in ${ }^{\circ} \mathrm{B} \times \mathrm{Y}$ can be attributed to the increases in yield.
A comparison of all progenies with their corresponding sources within a given cultivar was facilitated by performing the analysis of variance within each cultivar group. Most selected plants exceeded their source cultivars in yield with exceptions of 'Interpeel ${ }^{2}$ ' (selection site Muradiye) and 'VF 6203' (selection site Muradiye) in the Karacabey trial and 'C-37' (selection site Muradiye), 'Interpeel' ${ }^{1}$ (selection site Karacabey), 'Rio Fuego' (selection site Karacabey; source 1), 'VF 6203' (selection site Karacabey; source 5) and 'VF 6203' (selection site Muradiye) in the Muradiye trial. The figures for ${ }^{\circ} \mathrm{B} \times \mathrm{Y}$ values were similar to that of the yield. C-37 subpopulations were the top performing populations in terms of both yield and ${ }^{\circ} \mathrm{B} \times \mathrm{Y}$. Yield reached a peak of $3.01 \mathrm{~kg} / \mathrm{plant}$ (selection site Karacabey) in the Muradiye trial, while it reached maximum 2.85 $\mathrm{kg} /$ plant in 'C-37' (selection site Muradiye) in the Karacabey trial. The selection of one progeny for the production in both regions seems possible in most cases (e.g., 'C-37' progenies from both selection sites). Hence, only a weak relationship was apparent between the selection site and final performance of a given cultivar in that site.

Heritability for yield after two selection cycles is presented in Table 3 , which ranged from -0.04 to 0.62 in the Karacabey trial, and from -0.09 to 0.52 in the Muradiye trial. In general, higher $h^{2}$ values were obtained in the Karacabey trial than in the Muradiye trial. The values for $h^{2}$ were usually higher for well-performing progenies identified in Table 2. However, in several cases high ranking cultivars were not necessarily those with the highest $h^{2}$ estimates. The top ranking cultivar ' $\mathrm{C}-37$ ' in the Muradiye trial (selection site Muradiye with $3.01 \mathrm{~kg} /$ plant yield), for instance, had a comparatively low $h^{2}$ value $(0.20)$. In most other top ranking progenies $h^{2}$ estimates were consistent with their yield ranking (e.g., 'C-37' and 'T2 Improved' from selection site Muradiye).

\section{Discussions}

Most of the genetic improvement in processing tomatoes has been attributed to the replacement of inbred OP cultivars with hybrids during the past 20 years such as in California and Israel where hybrids have almost completely overtaken the seed market in processing tomatoes (Grandillo et al., 1999). However, OPs may still be preferred by resource-poor farmers in developing countries and the degree of genetic improvement achieved after two cycles of selection appears satisfying for this purpose. 'C-37' from source 1 (selection site Karacabey); 'Interpeel ${ }^{1}$ ' (for Karacabey production) and 'Interpeel' (for Muradiye production) both from source 4; 'Rio Fuego' from source 5 (selection site Karacabey); 'Rio Grande' from source 6 (selection site Muradiye); 'T2 Improved' from source 5 (selection site Muradiye) and 'VF 6203' from source 2 (selection site Karacabey) can be regarded as promising selections and may be included to further tests.

A high degree of $\sigma^{2}$ for yield was found within most of the OP subpopulations in both regions, which can be regarded as an indication of genetic variation within these OPs. A likely reason might be the genetic drift in varieties not being homozygous, where frequencies of non-favored alleles increase in uncontrolled reproduction cycles resulting

Table 1. Initial populations and their subpopulations in 2001; $\mathrm{n}_{\mathrm{j}}=$ number of evaluated individuals; $\mathrm{n}_{\mathrm{i}}=$ number of selected individuals as starting material, $\sigma_{p}^{2}=$ phenotypic variance. Selection continued only in those marked with an asterix in the $n_{i}$ column.

\begin{tabular}{|c|c|c|c|c|c|c|c|}
\hline \multirow[b]{3}{*}{ Cultivar } & \multirow{3}{*}{$\begin{array}{c}\text { Source } \\
\text { no. }\end{array}$} & \multicolumn{6}{|c|}{ Selection site } \\
\hline & & \multicolumn{3}{|c|}{ Karacabey } & \multicolumn{3}{|c|}{ Muradiye } \\
\hline & & $\mathrm{n}_{\mathrm{i}}$ & $\mathrm{n}_{\mathrm{i}}$ & $\sigma_{p}^{2}$ & $\mathrm{n}_{\mathrm{i}}$ & $\mathrm{n}_{\mathrm{i}}$ & $\sigma_{p}^{2}$ \\
\hline $\bar{C}-37$ & 1 & 436 & $12^{*}$ & 1.19 & 456 & $6^{*}$ & 0.66 \\
\hline C-37 & 2 & 430 & 6 & 0.77 & 415 & --- & 0.35 \\
\hline C-37 & 5 & 452 & 8 & 1.17 & 440 & --- & 0.25 \\
\hline Interpeel $^{1}$ & 4 & 436 & $7^{*}$ & 1.46 & 444 & 8 & 0.96 \\
\hline Interpeel $^{2}$ & 4 & 472 & 6 & 1.69 & 445 & $12^{*}$ & 1.09 \\
\hline Interpeel & 6 & 442 & --- & 0.19 & 448 & 10 & 1.02 \\
\hline Rio Fuego & 1 & 418 & $10^{*}$ & 0.96 & 443 & $10^{*}$ & 0.79 \\
\hline Rio Fuego & 2 & 460 & 9 & 1.01 & 423 & $7^{*}$ & 0.79 \\
\hline Rio Fuego & 5 & 467 & $10^{*}$ & 1.02 & 452 & 8 & 0.45 \\
\hline Rio Fuego & 6 & 485 & 9 & 1.25 & 363 & 11 & 0.70 \\
\hline Rio Fuego & 7 & 456 & 7 & 1.11 & 545 & --- & 0.32 \\
\hline Rio Grande & 1 & 430 & --- & 0.21 & 435 & 7 & 0.60 \\
\hline Rio Grande & 2 & 426 & $9^{*}$ & 0.98 & 452 & $10^{*}$ & 1.32 \\
\hline Rio Grande & 3 & 421 & $8^{*}$ & 0.71 & 436 & 8 & 0.38 \\
\hline Rio Grande & 4 & 453 & 9 & 0.57 & 470 & 11 & 0.44 \\
\hline Rio Grande & 5 & 434 & 7 & 0.97 & 458 & 9 & 0.64 \\
\hline Rio Grande & 6 & 423 & $11^{*}$ & 1.40 & 485 & $7^{*}$ & 1.36 \\
\hline Rio Grande & 7 & 444 & --- & 0.13 & 451 & --- & 0.29 \\
\hline Rio Grande (round) & 1 & 421 & 10 & 1.39 & 457 & 6 & 1.20 \\
\hline Rio Grande (Yalova) & 7 & 470 & --- & 0.15 & 445 & 6 & 0.49 \\
\hline T2 Improved & 1 & 469 & 11 & 1.09 & 433 & 5 & 0.55 \\
\hline T2 Improved & 5 & 442 & $7^{*}$ & 1.41 & 436 & $9^{*}$ & 0.95 \\
\hline T2 Improoved & 7 & 467 & --- & 0.30 & 400 & 8 & 1.36 \\
\hline VF 6203 & 2 & 518 & $9^{*}$ & 1.07 & 388 & 11 & 0.69 \\
\hline VF 6203 & 5 & 517 & $7^{*}$ & 2.03 & 447 & 12 & 0.82 \\
\hline VF 6203 & 7 & 477 & 6 & 1.56 & 432 & $10^{*}$ & 1.45 \\
\hline Total & & 11765 & 178 & & 11499 & 191 & \\
\hline
\end{tabular}


in a loss of cultivar purity. The extent of the reproduction cycles to the long term may have enhanced this phenomenon. The reason for genetic differences among the subpopulations of the same cultivar may also be a reflection of differential genetic constitutions of subpopulations of a given cultivar before their entrance to Turkey. Spontaneous mutations may also have accumulated during the long reproduction and cultivation processes, and played a role in the loss of cultivar purity (Tigchelaar, 1986). However, the potential of out-crossing in certain varieties may not be excluded. Even in mainly autogamous species it is not uncommon

that a certain degree of outcrossing occurs after many generation cycles (Hucl, 1996; Wang et al., 1997). Despite the fact that tomato is essentially self-pollinated, allo-pollen from adjacent fields may have arrived and resulted in cross-pollination under certain conditions, especially under stressful conditions (Tigchelaar, 1986). A cultivar mixture may than have resulted after a gene flow within a long-term reproduction cycle.

Slightly higher $\sigma^{2}$ values recorded for the Karacabey district elucidates a better phenotypic expression in yield at this site, possibly due to more favorable climatic conditions at the

Table 2. Changes in yield and ${ }^{\circ} \mathrm{B} \times \mathrm{Y}$ after two selection cycles for two experimental sites in 2003. Note: Duncan's multiple range tests are within cultivars only, not across the entire column or table; ${ }^{\circ} \mathrm{B} \times \mathrm{Y}=$ obrix $\times$ yield $/ 100$.

\begin{tabular}{|c|c|c|c|c|c|c|}
\hline \multirow[b]{3}{*}{ Cultivar } & \multirow[b]{3}{*}{$\begin{array}{l}\text { Selection } \\
\text { site }\end{array}$} & \multirow[b]{3}{*}{$\begin{array}{l}\text { Selection } \\
\text { no. }\end{array}$} & \multicolumn{4}{|c|}{ Trial } \\
\hline & & & \multicolumn{2}{|c|}{ Karacabey } & \multicolumn{2}{|c|}{ Muradiye } \\
\hline & & & $\begin{array}{c}\text { Yield } \\
\text { (kg/plant) }\end{array}$ & $\begin{array}{c}{ }^{\circ} \mathrm{B} \times \mathrm{Y} \\
(\mathrm{kg} / \text { plant })\end{array}$ & $\begin{array}{c}\text { Yield } \\
\text { (kg/plant) }\end{array}$ & $\begin{array}{c}{ }^{\circ} \mathrm{B} \times \mathrm{Y} \\
(\mathrm{kg} / \text { plant })\end{array}$ \\
\hline$\overline{C-37}$ & Karacabey & Selected 1 & $2.65 \mathrm{a}$ & $0.134 \mathrm{a}$ & $3.01 \mathrm{a}$ & $0.158 \mathrm{a}$ \\
\hline \multirow[t]{2}{*}{ C-37 } & Muradiye & Selected 1 & $2.85 \mathrm{a}$ & $0.142 \mathrm{a}$ & $2.48 \mathrm{~b}$ & $0.131 \mathrm{~b}$ \\
\hline & & Source 1 & $1.94 \mathrm{~b}$ & $0.101 \mathrm{~b}$ & $2.62 \mathrm{~b}$ & $0.131 \mathrm{~b}$ \\
\hline \multirow[t]{2}{*}{ Interpeel $^{1}$} & Karacabey & Selected 4 & $2.55 \mathrm{a}$ & $0.134 \mathrm{a}$ & $1.94 \mathrm{c}$ & $0.102 \mathrm{c}$ \\
\hline & & Source $4^{1}$ & $2.14 \mathrm{~b}$ & $0.107 \mathrm{~b}$ & $1.97 \mathrm{bc}$ & $0.104 \mathrm{bc}$ \\
\hline \multirow[t]{2}{*}{ Interpeel $^{2}$} & Muradiye & Selected 4 & $2.06 \mathrm{~b}$ & $0.106 \mathrm{~b}$ & $2.37 \mathrm{a}$ & $0.119 \mathrm{a}$ \\
\hline & & Source $4^{2}$ & $1.92 \mathrm{~b}$ & $0.101 \mathrm{~b}$ & $2.17 \mathrm{ab}$ & $0.116 \mathrm{ab}$ \\
\hline Rio Fuego & Karacabey & Selected 1 & $2.05 \mathrm{~cd}$ & $0.106 \mathrm{~b}-\mathrm{d}$ & $2.09 \mathrm{~b}$ & $0.104 \mathrm{~b}$ \\
\hline \multirow[t]{2}{*}{ Rio Fuego } & Muradiye & Selected 1 & $2.22 \mathrm{bc}$ & $0.113 \mathrm{bc}$ & $2.35 \mathrm{a}$ & $0.119 \mathrm{a}$ \\
\hline & & Source 1 & $1.76 \mathrm{e}$ & $0.093 \mathrm{~d}$ & $2.06 \mathrm{~b}$ & $0.104 \mathrm{~b}$ \\
\hline \multirow[t]{2}{*}{ Rio Fuego } & Muradiye & Selected 2 & $2.24 \mathrm{~b}$ & $0.118 \mathrm{~b}$ & $2.25 \mathrm{ab}$ & $0.123 \mathrm{a}$ \\
\hline & & Source 2 & $1.93 \mathrm{de}$ & $0.098 \mathrm{~cd}$ & $1.77 \mathrm{c}$ & $0.093 \mathrm{c}$ \\
\hline \multirow[t]{2}{*}{ Rio Fuego } & Karacabey & Selected 5 & $2.59 \mathrm{a}$ & $0.136 \mathrm{a}$ & $2.42 \mathrm{a}$ & $0.124 \mathrm{a}$ \\
\hline & & Source 5 & $2.23 \mathrm{bc}$ & $0.116 b$ & $2.25 \mathrm{ab}$ & $0.118 \mathrm{a}$ \\
\hline Rio Grande & Karacabey & selected 2 & $2.11 \mathrm{ab}$ & $0.107 \mathrm{ab}$ & $2.29 \mathrm{ab}$ & $0.124 \mathrm{a}-\mathrm{c}$ \\
\hline \multirow[t]{2}{*}{ Rio Grande } & Muradiye & selected 2 & $2.19 \mathrm{ab}$ & $0.108 \mathrm{ab}$ & $2.46 \mathrm{a}$ & $0.134 \mathrm{a}$ \\
\hline & & Source 2 & $1.61 \mathrm{~d}$ & $0.083 \mathrm{~d}$ & $1.94 \mathrm{c}$ & $0.102 \mathrm{~d}$ \\
\hline \multirow[t]{2}{*}{ Rio Grande } & Karacabey & selected 3 & $2.17 \mathrm{ab}$ & $0.117 \mathrm{a}$ & $2.18 \mathrm{bc}$ & $0.110 \mathrm{~cd}$ \\
\hline & & Source 3 & $1.68 \mathrm{~cd}$ & $0.086 \mathrm{~cd}$ & $1.91 \mathrm{c}$ & $0.098 \mathrm{~d}$ \\
\hline Rio Grande & Karacabey & selected 6 & $2.23 \mathrm{ab}$ & $0.116 \mathrm{a}$ & $2.36 \mathrm{ab}$ & $0.123 \mathrm{a}-\mathrm{c}$ \\
\hline \multirow[t]{2}{*}{ Rio Grande } & Muradiye & selected 6 & $2.34 \mathrm{a}$ & $0.116 \mathrm{a}$ & $2.36 \mathrm{ab}$ & $0.126 \mathrm{ab}$ \\
\hline & & Source 6 & $1.91 \mathrm{bc}$ & $0.097 \mathrm{bc}$ & $2.11 \mathrm{bc}$ & $0.115 \mathrm{bc}$ \\
\hline T2 Improved & Karacabey & selected 5 & $2.13 \mathrm{a}$ & $0.109 \mathrm{~b}$ & $2.13 \mathrm{~b}$ & $0.115 \mathrm{~b}$ \\
\hline \multirow[t]{2}{*}{$\mathrm{T} 2$ Improved } & Muradiye & selected 5 & $2.37 \mathrm{a}$ & $0.125 \mathrm{a}$ & $2.54 \mathrm{a}$ & $0.137 \mathrm{a}$ \\
\hline & & Source 5 & $1.83 \mathrm{~b}$ & $0.096 \mathrm{~b}$ & $1.64 \mathrm{c}$ & $0.091 \mathrm{c}$ \\
\hline \multirow[t]{2}{*}{ VF 6203} & Karacabey & Selected 2 & $2.48 \mathrm{a}$ & $0.128 \mathrm{a}$ & $2.22 \mathrm{a}$ & $0.117 \mathrm{a}$ \\
\hline & & Source 2 & $2.05 \mathrm{bc}$ & $0.108 \mathrm{bc}$ & $1.86 \mathrm{~b}$ & $0.101 \mathrm{~b}$ \\
\hline \multirow[t]{2}{*}{ VF 6203} & Karacabey & Selected 5 & $2.18 \mathrm{ab}$ & $0.112 \mathrm{~b}$ & $1.88 \mathrm{~b}$ & $0.102 \mathrm{~b}$ \\
\hline & & Source 5 & $1.83 \mathrm{~b}-\mathrm{d}$ & $0.096 \mathrm{~cd}$ & $1.78 \mathrm{~b}$ & $0.093 \mathrm{bc}$ \\
\hline \multirow[t]{2}{*}{ VF 6203} & Muradiye & Selected 7 & $1.62 \mathrm{~d}$ & $0.082 \mathrm{e}$ & $1.66 \mathrm{~b}$ & $0.086 \mathrm{~cd}$ \\
\hline & & Source 7 & $1.71 \mathrm{~cd}$ & $0.093 \mathrm{de}$ & $1.57 \mathrm{~b}$ & $0.079 \mathrm{~d}$ \\
\hline
\end{tabular}

Table 3. Realized heritabilities $\left(\mathrm{h}^{2}\right)$, at the basis of selection sites after two selection cycles.

\begin{tabular}{lcccc}
\hline & Selection & Source & \multicolumn{2}{c}{ Trial } \\
\cline { 2 - 4 } Cultivar & site & no. & Karacabey & Muradiye \\
\hline C-37 & Karacabey & 1 & 0.36 & 0.20 \\
C-37 & Muradiye & 1 & 0.62 & -0.09 \\
Interpeel $^{1}$ & Karacabey & 4 & 0.12 & -0.01 \\
Interpeel $^{2}$ & Muradiye & 4 & 0.07 & 0.10 \\
Rio Fuego $_{\text {Rio Fuego }}$ & Karacabey & 1 & 0.17 & 0.02 \\
Rio Fuego & Muradiye & 1 & 0.30 & 0.19 \\
Rio Fuego & Muradiye & 2 & 0.19 & 0.30 \\
Rio Grande & Karacabey & 5 & 0.18 & 0.08 \\
Rio Grande & Karacabey & 2 & 0.35 & 0.25 \\
Rio Grande & Muradiye & 2 & 0.22 & 0.19 \\
Rio Grande & Karacabey & 3 & 0.50 & 0.27 \\
Rio Grande & Karacabey & 6 & 0.13 & 0.10 \\
T2 Improved & Muradiye & 6 & 0.16 & 0.09 \\
T2 Improved & Karacabey & 5 & 0.12 & 0.20 \\
VF 6203 & Muradiye & 5 & 0.31 & 0.52 \\
VF 6203 & Karacabey & 2 & 0.20 & 0.17 \\
VF 6203 & Karacabey & 5 & 0.09 & 0.03 \\
& Muradiye & 7 & -0.04 & 0.04 \\
\hline
\end{tabular}

Karacabey district in contrast to the Muradiye district (Vural et al., 2000).

A strong negative relation between ${ }^{\circ}$ brix and yield is often reported in processing tomatoes (Tanksley et al., 1996), which was the main reason of testing ${ }^{\circ}$ brix values of selected progenies against their parental sources in this study. Since in the present study, differences in ${ }^{\circ}$ brix values of progenies and parents were statistically not significant, it could be concluded that the negative correlation of ${ }^{\circ}$ brix and fresh fruit yield is not pronounced in the high yielding individuals of our material. That the changes in the derived parameter ${ }^{\circ} \mathrm{B} \times \mathrm{Y}$ are parallel to the changes in yield supports this conclusion. Regarding its polygenic nature (Ibarbia and Lambeth, 1969), similar segregations to that of the yield may also be expected within the ${ }^{\circ}$ brix values. This would have to be tested whether there is any further improvement possible in ${ }^{\circ}$ brix within our material by selecting for this trait.

At present we do not know the true yield difference between OPs and hybrids in the developing countries. However, when the excessive reproduction cycles and the lack of maintenance breeding are regarded, yield difference might be as high as 30\% (Vural et al., 2000). High seed import costs should also be considered when the real benefit of the hybrids is outlined. Under the competitive nature of the seed industry, the market shares of most successful varieties are seldom estimated for $>4$ or 5 years, which would mean wasting resources in developing countries where the cultivation is mainly based on imported production material (Grandillo et al., 1999; Vural et al., 2000). Testing the adaptation of hybrids in different regions is often not done and many hybrids do not yield well in many of these environments (Gallardo and Calvar, 1992). Hence, processors prefer hybrids not only for high ${ }^{\circ} \mathrm{B} \times \mathrm{Y}$ value and yield, but also for governed resistance to major pests and diseases, which are only problems at some sites and soils (Erkan et al., 1996; Gallardo and Calvar, 1992). The need for improved OPs might be more pronounced when the low socioeconomical status of most farmer families in rural areas of Turkey is considered (Blake et al., 2003). In contrast to developed countries, agriculture is being practiced mostly by smallscale farmers, which would possibly accept a certain degree of low yields for high prices, especially in non-infected sites and soils (Gallardo and Calvar, 1992; Tikoo, 1987).

The situation described above is in favor for the continuation of the cultivation of OP cultivars, which have been widely neglected due to the losses in yield after many reproduction cycles during the past 20 to 30 years. Distribution of our selected material into commercial fields seems feasible since even resource poor farmers commonly express their willingness to pay a certain amount for maintained seeds instead of genetically degraded seeds (Jones et al., 2001). This will enhance the cultivation of OPs vs. hybrids by the small-scale farmers with limited resources, who would, due to financial limitations, even use segregated populations (e.g., $\mathrm{F}_{2} \mathrm{~s}$ ) for the production (Gallardo and 
Calvar, 1992; Tikoo, 1987). We expect that the improved OPs would fill a niche market for the next decade in Turkey. Paste and seed companies collaborated with show interest in our improved OPs and express their willingness to replace their seed-stocks. However, further demonstration studies should be planned to introduce the improved OPs to other food companies and extend their usage in processing tomato production. One promising representative of each cultivar might be used for this purpose. The continuation of the controlled reproduction of the selected material combined with formal seed distribution will be useful in the future to prevent possible genetic shift towards low yielding populations. This may also enable authorities to perform systematic seed sampling for the control of seed borne viral and bacterial diseases (Blake et al., 2003; Vural et al., 2000).

\section{Literature Cited}

Turkish Republic Ministry of Agriculture and Rural Affairs. 2002. Program on national supply, distribution and production of seeds. Turkish Rep. Min. Agr. Rural Affairs.

Blake, D., T. Yoltas, and S. Erkan. 2003. The recent situation of the processing tomato industry in Turkey. Acta Hort. 613:437-441.

Erkan, S., M. Gümüs, and I. Duman. 1996. Marmara bölgesinin degisik yörelerinde sanayi domatesi yetistiriciliginin özelliklerinin ve sorunlarının belirlenmesine yönelik bir arastırma (Turkish with English summary). SANDOM Res. Rpt. 10:1-22. Albayrak press, Izmir.

Eshed, Y., G. Gera, and D. Zamir. 1996. A genomewide search for wild-species alleles that increase horticultural yield of processing tomatoes. Theor. Appl. Genet. 93:877-886.

Falconer, D.S. 1989. Introduction to quantitative genetics. Longman Scientific \& Technical, U.K.

FAOSTAT. 2004. February 2004. http://foastat. fao.org.

Lallardo, G.S. and D.J. Calvar. 1992. Tomato for industry breeding program in Argentina. Acta Hort. 301:87-90.

Grandillo, S., D. Zamir, and S.D. Tanksley. 1999. Genetic improvement of processing tomatoes: A 20 years perspective. Euphytica 110:85-97.

Hucl, P. 1996. Out-crossing rates for 10 Canadian spring wheat cultivars. Can. J. Plant Sci. 76:423-427.

Ibarbia, E.A. and V.N. Lambeth. 1969. Inheritance of soluble solids in a large/small-fruited tomato cross. J. Amer. Soc. Hort. Sci. 94:496-498.

Jones, R.B., P.A. Audi, and R. Tripp. 2001. The role of informal seed systems in disseminating modern varieties. The example of pigeonpea from a semi-arid area of Kenya. Expt. Agr. 37:539-548.

Tanksley, S.D., S. Grandillo, M.T. Fulton, D. Zamir, Y.Eshed, V. Petiard, J. Lopez, and T. Beck-Bunn. 1996. Advanced backcross QTL analysis in a cross between an elite processing line of tomato and its wild relative L. pimpinellifolium. Theor. Appl. Genet. 92:935-951.

Tigchelaar, E.C. 1986. Tomato breeding,p. 135-171. In: M.J. Bassett (ed.). Breeding vegetable crops. Avi Publ. Co., Westport, Conn.

Tikoo, S.K. 1987. Breeding tomatoes for processing in India; present status and future prospects. Acta Hort. 200:73-81.

Vural, H. 1966. Heinz domates çesitlerinin kalitatif ve kantitatif özelliklerinin tespiti ve WC156 (UC.156) ile mukayesesi üzerinde arastırmalar (Turkish with English summary). J. Ege Univ. Fac. Agr. 7:35-50.

Vural, H., D. Esiyok, I. Duman, and E. Düzyaman, 2000. Adaptation to Aegean and Marmara Regions and evaluation of yield and quality properties of standard and $\mathrm{F}_{1}$ hybrid processing tomato varieties (in Turkish with English summary), p. 378-382. Proceedings of the III. National Symposium on Vegetable Growing, SDÜ, Isparta.

Wang, T.Y., H.B. Chen, X. Reboud, and H. Darmency. 1997. Pollen-mediated gene flow in an autogamous crop: Foxtail millet (Setaria italica). Plant Breed. 116:579-583. 